\title{
Organizational and technological genesis as a tool for strategic planning of large-scale real estate development projects
}

\author{
Elena Gusakova ${ }^{1, *}$ \\ ${ }^{1}$ Moscow State University of Civil Engineering, Yaroslavskoye shosse, 26, 129337, Moscow, Russia
}

\begin{abstract}
Conceptual planning and implementation of large-scale real estate development projects is one of the most difficult tasks in the organization of construction. In the Russian practice, a large experience of development, complex reorganization and redevelopment of large development areas is accumulated. The methodological basis for solving similar problems is the organizational and technological genesis, which considers the development of the project during the full life cycle. An analysis of this experience allows us to talk about the formation of new and effective approaches and methods within the organizational and technological genesis. Among them, the most significant and universal approaches should be highlighted: The concept of real estate development, which explains the reasons and objective needs for project transformations during its life cycle, as well as to increase the adaptive capabilities of design decisions and the project's suitability for the most likely future changes; Development project of joint action, which is based on the balance of interests of project participants; Master planning of the life cycle stages of the project and subprojects, based on the rethinking of the theory and methods of the construction organization, and allowing rationally localized construction sites and related subprojects, while retaining the remaining development and development area beyond of the negative effect of construction for comfortable living and work.
\end{abstract}

\section{Introduction}

As a rule, large-scale real estate development projects are closely connected with megacities. Large-scale real estate development projects reflect the strategy and evolution of their progress and extension, therefore remain relevant irrespective of the crisis phenomena. Retrospective development of the largest cities in the world shows that the most significant development projects or "megaprojects" are being developed with the goals of updating built-up depressed urban areas and development of new territories metropolitan satellites. The term "megaproject" came to Russia from the West, where large-

*Corresponding author: e_gusakova@inbox.ru 
scale and complex construction projects stand out as a separate class of projects. They are characterized not only by significant financial and labor costs, tangible impact on the surrounding area, but also by complex organizational schemes and a large number of participants, strategically long terms of implementation, and heterogeneity of construction projects.

Megaprojects remain attractive and interesting for investment regardless of the crisis phenomena, in connection with which a stable trend of growth in the scale and complexity of construction projects is formed and there is a need to develop common organizational and technological approaches to the implementation of such projects.

\section{Materials and methods}

Systematization of the successful projects experience, of the large-scale development, of large areas of obsolete, depressed and abandoned buildings and their integration into the modern urban space allows us to speak about the effectiveness of such concepts, methods and organizational approaches as: organizational and technological genesis, based on the adaptability of the technological design of the project and the structure of change management processes; the concept of real estate development; development project of joint action, based on the balance of interests of participants; as well as master planning of organizational stages and sub-projects, based on the rethinking of the theory of flow in construction.

\section{Results}

Large-scale real estate development projects began to be planned and implemented in Russia in the 2000s, when the real estate market was at the stage of intensive recovery. Due to the development of the land market, companies began to appear in the ownership of which significant areas for construction were located. This allowed the developers to plan large-scale, organizationally and technologically complex and investment-construction mega-projects. The largest engineering companies and developers have created projects for the erection of self-sufficient complexes of objects on their lands - practically city-satellites of megacities with industries, jobs, with their own transport and social infrastructure. The subsequent downturns and crises of the real estate market led to the fact that some former landowners were forced to transfer their assets to creditors because of debts. So, among the owners of the largest land areas there were large banking structures. With the change in conditions, the goals, scope and composition of developers were repeatedly and substantially corrected, the concept of megaprojects was suspended or changed, most of the projects were subject to revision and redevelopment. At the same time, the analysis of international experience and patterns of development allows us to conclude that the high dynamics of external and internal parameters is a long-term and objective condition for the implementation of large-scale projects. Nevertheless, as practice shows, the tasks of development and implementation of such development projects have been relevant for many years and remain relevant. Land owners are ready to use their land assets for largescale development, realizing that the effectiveness of a separate project within the megaproject may be higher, and the risks are lower due to consolidation and so-called multiplicative effects [1-5].

In the Moscow region, projects to optimize the construction, reorganization and new use of large sections of industrial zones are planned very actively. In the urban development of the capital there are many successfully implemented projects. These projects of 
development of the territories of the out-of-date and abandoned buildings, depressive industrial zones allowed to integrate the city's territories into the modern urban space with new demanded urban facilities, including social institutions, work and rest places. In Moscow, to date, more than a dozen industrial development sites have been reconstructed. And at present projects are being implemented at twenty sites of former factories, warehouses and factories [6]. At the same time, if earlier such projects appeared only on the territory of the Moscow region, now they are planned in Moscow. One of the largest megaprojects in the Moscow region is "A101" (an area of 13 thousand hectares) in the territory of New Moscow and "Big Domodedovo", an area of 3 thousand hectares, where various types of residential and commercial real estate, infrastructure and production facilities are being built.

Within the boundaries of the "old" Moscow, historically there are more than 200 old industrial areas and sites with a total area of about 20,000 hectares, where industrial, scientific, municipal and special facilities are located. According to the Moscow government, about $24 \%$ of the city's enterprises are unprofitable, many enterprises do not meet modern sanitary and environmental standards, and the average wear of corresponding fixed assets is more than $47 \%$. Efficiently employs about $30 \%$ of plants and factories, and the rest are not used for their intended purpose, receiving the main profit by renting out areas. Currently, outdated industrial buildings and depressed industrial areas are considered by the city authorities as the main territorial potential of the city's strategic development and the largest reserve of location of city facilities of the State programs of Moscow and the creation of a more comfortable and permeable urban environment. A number of administrative documents of the government of Moscow, substantiating the principle of complex reorganization of production areas, including due to their quantitative reduction and transition to a compact location of science and industry facilities in industrial zones of the city, were developed and approved. According to the department, a total of plans are currently being developed for the reorganization of the territory of the industrial development of the metropolis [6]. Since a big city cannot exist without an industry, the General Plan for the development of the capital until 2020 does not imply a complete withdrawal of production from Moscow. The area of the remaining industrial development should be from 15 thousand hectares to $10 \div 12$ thousand hectares. At the same time, industrial enterprises that are being preserved or newly built in the city should be oriented to the needs of the city, to high-tech jobs, to innovative technologies and compliance with modern environmental requirements for production located within the metropolis.

\section{Discussion}

Megaprojects are implemented for a long time, often more than 10 years. They involve large amounts of long-term investments, not only for new construction, but also for preparing the territory, for dismantling existing structures, for removing construction debris and for reclamation of soils, for renovating or relocating existing production to another area. Investments are also required for renewal of infrastructure, restoration of preserved objects and buildings, which are architectural monuments. Organizational and technological approaches to the construction of objects in a large-scale project require a sound strategy for organizing and coordinating the stages or sub-projects. In the framework of which the tasks of optimization of infrastructure and communication, the relocation of enterprises, facilities and structures, coordination of relevant legal, regulatory procedures, financial relations and legal and urban issues should be solved. 
The megaprojects construction organization requires the consideration in the long-term planning of the investment and construction process the cyclical patterns of acroeconomics, much more complex project analysis and consolidation of the stages and participants of the project. As practice shows, their implementation is only possible by large specialized construction and engineering companies [7-12].

Over the past years, the professional community has accumulated substantial experience in the comprehensive reorganization of large territories, which allows us to talk about the formation of new promising organizational and technological methods for such large-scale development projects [13-17].

Large-scale development projects change the surrounding buildings and often themselves are subject to changes in the concept of the project and other transformations in the implementation process. As a consequence, the development of real estate becomes a permanent factor in the global economy. A corresponding methodological concept with universal set priorities was also formed. They are as follows:

1. The transformation of the real estate object is inevitable and objectively necessary in the conditions of accelerating changes, the dynamics of the market and the structure of demand;

2. Development needs can arise at any stage in the life cycle of a estate;

3. The trend of real estate development is expedient to forecast, plan and take into account at the initial stages of project development;

4. The more development opportunities there are for a real estate object, the higher the potential of its functionality and the more effectively its life cycle can be realized [14].

This concept of real estate development in modern conditions is an analytical and methodological basis for the adoption of organizational solutions and project management.

For large-scale projects, the issues of development of approaches and methods of change management that are inevitable in the implementation of long-term development projects become extremely demanded. There is a need for technologies to regulate changes that allow, if necessary, to make changes to the project as technologically as possible at virtually any stage [14, 18-20]. The choice of technologies for change management is determined by the adaptability of the project to changes or its adaptability, which is directly determined by the extent to which the most probable possibilities for changes and development of all its subsystems are thought through in the organizational and economic mechanisms for implementing the project.

Management of the megaproject changes from this point of view is methodologically close to genesis as a method of research. Genesis focuses attention on the future of the project, considers it as a developing system, all of its characteristics are due to cause-effect relationships and are adequate to the changing conditions of the external environment. The justification of solutions by methods of organizational and technological genesis is the initial condition of the project's fitness for changes, its adaptive technologicality. Dynamic classes of models can be used for this, and traditional project analysis is supplemented by anticipatory consideration of counter information flows and feedbacks based on predicting regularities, scenarios and specific parameters of the project life cycle at pre-investment stages.

Methodically, the regulation of changes in a development or redevelopment project requires the study of potential changes, the systematization of sources and causes of changes, and the structuring of change procedures in the process of implementing the project life cycle. To ensure that the processes of making changes to the project at all stages of its life cycle are carried out technologically and efficiently, it is necessary to ensure their maximum possible formalization and unambiguous algorithm of actions - the basis of the technology for regulating changes. The accumulated experience of making changes in 
investment and construction projects at various stages of their implementation can be systematized in large part on the basis of typical or most frequently repeated processes. On this basis, the structure of the processes of regulating changes is constructed, encompassing the complete sequence of typical processes with the determinants of the beginning and completion of each of them: from the emergence of the need for change to its full realization (Table 1).

Table 1. Structure of the processes of regulation of changes.

\begin{tabular}{|l|l|l|l|}
\hline$\#$ & $\begin{array}{l}\text { Steps for adjusting the } \\
\text { change }\end{array}$ & $\begin{array}{l}\text { Determinant of the } \\
\text { beginning }\end{array}$ & Determinant of the completion \\
\hline 1 & $\begin{array}{l}\text { Identifying the problematic } \\
\text { subsystem of the project }\end{array}$ & Subsystem of the problem & $\begin{array}{l}\text { There is no problem in the } \\
\text { subsystem }\end{array}$ \\
\hline 2 & $\begin{array}{l}\text { Determination of the causes } \\
\text { and consequences of the } \\
\text { problem }\end{array}$ & $\begin{array}{l}\text { Database and knowledge } \\
\text { base on the problem } \\
\text { subsystem }\end{array}$ & $\begin{array}{l}\text { The list of possible changes } \\
\text { (solutions to the problem) }\end{array}$ \\
\hline 3 & $\begin{array}{l}\text { Formulation of acceptable } \\
\text { changes }\end{array}$ & List of possible changes \\
\hline 4 & $\begin{array}{l}\text { Substantiation of the optimal } \\
\text { mechanism of change }\end{array}$ & $\begin{array}{l}\text { List of permissible } \\
\text { changes }\end{array}$ & $\begin{array}{l}\text { List of permissible changes } \\
\text { changing }\end{array}$ \\
\hline 5 & $\begin{array}{l}\text { Predicting the consequences } \\
\text { of a change }\end{array}$ & $\begin{array}{l}\text { Acceptable mechanism of } \\
\text { the change }\end{array}$ & $\begin{array}{l}\text { Plan for changing the } \\
\text { subsystem }\end{array}$ \\
\hline 6 & $\begin{array}{l}\text { Harmonization of the content } \\
\text { and mechanism of change }\end{array}$ & $\begin{array}{l}\text { Plan for changing the } \\
\text { subsystem }\end{array}$ & $\begin{array}{l}\text { Plan for the organization and } \\
\text { production of work on the } \\
\text { modification of the subsystem, } \\
\text { responsible persons }\end{array}$ \\
\hline 7 & $\begin{array}{l}\text { Approval of a change plan } \\
\text { plan for the organization and } \\
\text { production of work on } \\
\text { changing the subsystem - } \\
\text { responsible persons are } \\
\text { established }\end{array}$ \\
\hline 8 & $\begin{array}{l}\text { Plan for the organization } \\
\text { and production of work } \\
\text { on changing the } \\
\text { subsystem is developed }\end{array}$ & $\begin{array}{l}\text { Performance monitoring } \\
\text { the changed project } \\
\text { subsystem }\end{array}$ & Change plan completed \\
\hline
\end{tabular}

The structure of causes and processes of project changes can form the basis for regulating project changes based on the most common (typical) procedures and processes, organizational mechanisms and technologies for implementing changes and transformations. The development of such a technique is necessary in the conditions of the objective inevitability of changes. Moreover, it is extremely in demand and is of practical interest for development and management companies implementing large-scale construction projects.

Development of large metropolitan areas and large-scale modernization of buildings is practically impossible without the strategic cooperation of the developer and city and federal authorities [6]. With the worked out organizational and economic mechanism of such interaction, the developers are provided with real assistance in solving infrastructure problems, which makes it possible to implement projects more actively. City authorities can take on some of the tasks of infrastructure development, including transport in the development projects of industrial zones. An example of effective cooperation and joint efforts of the city and the investor in Moscow is the project for the development of the former industrial zone "Nagatinsky Zaton", where city authorities have undertaken the 
construction of a metro station. For the success of this joint project, the balance of interests of stakeholders affected by the project for the development of a specific territory and the development of a general concept of its development that involves the interests of different strata of the population of the surrounding development and the megapolis as a whole was extremely important. Based on the balance of interests, the organizational model essentially forms the basis for a development project of joint action, on which the development of the project itself can begin. In this area, the activities of Moscow authorities on the development, reorganization and redevelopment of industrial and communal areas and industrial areas of Moscow are coordinated by the City Planning Department of Moscow. Here, proposals are being developed for the development of the appropriate types of town planning documentation required for urban development "disclosure" of the territory, including the development of options for town planning solutions that provide for the balance of city interests and interests of property owners. Here, decisions are made on the reservation of land, technical tasks for the development of land use planning projects; mandatory list of objects to be placed; projects of territory planning.

Among the organizational approaches to megaprojects, it is necessary to allocate master planning, which in many countries is an obligatory stage of work on large projects $[4,11$, 15]. In Russia, this approach is also being implemented. The master plan, unlike the planning project, is not a legal document, it can change in the course of the project implementation taking into account the forecasts and scenarios of development of the building site. When modeling a master plan:

- the town-planning features, architecture and history of the territory falling under the project are determining;

- scenarios of "embedding" the project in the existing built-up area and the environment are developing;

- the scenarios of "embedding" the project in the existing building and environment are justified;

- the task of combining the economic goals of the developer and public expectations is being solved.

Master planning as an organizational approach is effective in the implementation of projects related to the regeneration of territories, the redevelopment of industrial zones, the formation of a new urban environment in undeveloped areas. With integrated development of territories, the organization of interaction between the project participants is significantly changing - there is a need to justify and organize the stages of work or subprojects. Megaproject of development of large territories, each of which is occupied by dozens of objects and enterprises, should consider the territory simultaneously and entirely [4, 9]. At the same time, it is necessary to divide the megaproject into organizationally interconnected stages and justify their sequence. There arises the task of rethinking the theory of of flow in construction and methods for the flow organization of subprojects in order to compactly localize construction sites while preserving the rest of the development area for comfortable living and working outside the negative effects of construction. For example: first of all, existing buildings are reconstructed and mastered, at the next stage new objects are gradually added in such a way that the megaproject is realized "evolutionarily" and retains a comfortable environment for life and activity against the background of localized construction without becoming a global and endless construction project.

\section{Conclusions}


Organizational and technological genesis can be considered as a methodological basis for the development of strategic real estate development projects - megaprojects. They are closely connected with the development of megacities, reflect the cyclical strategy and evolution of their development, have a huge economic potential, and therefore remain relevant regardless of the crisis phenomena. Megaprojects require the solution of the most difficult professional tasks of the organization of construction. The analysis of the accumulated Russian and international experience in the development of large territories allows us to speak about the formation of new promising organizational concepts within megaprojects, such as:

- The concept of real estate development, based on the objective need for changes and the project's adaptive potential;

- Development project of joint action, based on the balance of interests of participants in the life cycle of the project;

- Master planning of organizational stages based on the rethinking of the theory of flow in construction with reference to the subprojects that make up the megaproject.

\section{References}

1. S. Baronin, A. Porshakova, Journal of Izvestia of the Penza State Pedagogical University 24, 200-203 (2011)

2. S. Glazyev, G. Fetisov, Economic and social changes: facts, trends, forecast 1(25), 1829 (2013)

3. P. Grabovyi, E. Gusakova, S. Lunyakov, Real Estate: Economics, Management 3-4, 74-79 (2014)

4. D. Kuzovleva, Marchenko Journal of FEN Science 8, 36-42 (2012)

5. Y. Lavrikova, S. Kotlyarova, Economic and social changes: facts, trends, forecast 3(33), 169-179 (2014)

6. A. Segaev, A. Porshakova, A. Vakina, O. Petrosova, Economics and entrepreneurship 10 (51), 305-310 (2014)

7. V. Baburin, Innovative cycles in the Russian economy (Krassand, Moscow, 2010)

8. E. Kolesnikova, T. Kuzmina, S. Sinenko, Solution of organizational and technological problems (Moscow, Publisher ASV, 2015)

9. T. Kuzmina, S. Sinenko, A. Slavin, Industrial and civil construction 6, 71-75 (2016)

10. A. Orlov, Economics and Entrepreneurship 6-3(59-3), 545-548 (2015)

11. A. Shuleshko, Scientific bulletins of the Belgorod State University 14-1-1, 53-59 (2010)

12. A. Ginzburg, A. Skiba, Applied Mechanics and Materials 584-586, 507-511 (2014)

13. A. Ginzburg, O. Baranova, N. Blokhina, A. Volkov, N. Garyaev, V. Ginzburg, V. Ignatov, E. Ignatova, B. Istomin, P. Kagan, E. Kitintseva, V. Kulikov, S. Sinenko, Systems of design automation in construction (Moscow State University of Civil Engineering, Moscow, 2014)

14. A. Ginzburg, Y. Lobyreva, D. Semernin, Scientific Review 16, 461-464 (2015)

15. E. Gusakova, Y. Ushakova, Real Estate: Economics, Management 1, 54-60 (2015)

16. A. Volkov, V. Chulkov, D. Korotkov, Advanced Materials Research 1065-1069, 2577 2580 (2014) 
17. A. Ginzburg, E. Nesterova, Scientific and Technical Journal Vestnik MGSU 5, 317320 (2011)

18. E. Gusakova, A. Krygina, Real Estate: Economics, Management 2, $84-87$ (2012)

19. S. Sinenko, E. Shtranina, Scientific review 6, 185-188 (2016)

20. A. Ginzburg, C. Kachanov, International Journal of Applied Engineering Research 1020, 40869-40872 (2015) 